\title{
Caatinga Tree Wood Anatomy: Perspectives on Use and Conservation
}

\author{
Aragão José Roberto Vieira ${ }^{1}$ (D), Claudio Sergio Lisi ${ }^{2}$ \\ ${ }^{1}$ Programa de Pós-graduação em Ecologia e Conservação - PPEC, Universidade Federal de Sergipe - UFS, \\ São Cristovão/SE, Brasil \\ ${ }^{2}$ Departamento de Biologia, Centro de Ciências Biológicas e da Saúde - CCBS, Universidade Federal de Sergipe - UFS, \\ São Cristovão/SE, Brasil
}

\begin{abstract}
This work describes the anatomical analysis of the wood of four Caatinga tree species in order to determine the anatomical characteristics necessary for species segregation in functional groups, to relate them to the regional environmental conditions, as well as to infer about their management and conservation. Qualitatively, the species showed peculiar adaptations to xeric environments such as high frequency of low caliber vessels or parenchyma cells. Quantitatively, the four taxa were divided into three functional groups related to the precipitation and temperature of the Caatinga. The relationships between anatomy and the environment have shown their vulnerability to climatic variations, and have warned of the damage that can be generated by anthropogenic action. It is advisable to use the energy of the species or for use in civil construction, with the exception of Tabebuia aurea, which is appropriate for carpentry. It was verified that the anatomy of the wood has potential as a subsidy for the use, management and conservation of the studied species.
\end{abstract}

Keywords: wood anatomy, xeric environments, functional groups. 


\section{INTRODUCTION}

Even though tropical forests cover less than 7 percent of the land surface, they play a key role in maintaining the balance of biogeochemical and hydrological cycles (Wright, 2010), as well as providing clean water, fuel and food for millions of people around the world (Schmidt \& Ticktin, 2012). These regions have high levels of biodiversity, contribute to one-third of primary terrestrial productivity (Bonan, 2008), and account for about 30\% of global carbon (Pan et al., 2011).

Tropical dry forests such as the Brazilian Northeast Caatinga are crucial to these ecosystem services and are vulnerable to changes in climate, as they occur in areas considered prone to change and with high concentrations of people (Pan et al., 2011). The population in these regions has a direct economic dependence on the forest products from the wood, which increases the pressure on the arboreal remnants and potentiates the effect of the climate on the vegetation (Araújo et al., 2007; Araujo et al., 2010; Albuquerque et al., 2012). Most of the demand generated by the population is concentrated on timber resources used for various purposes, from construction to energy use (Araújo et al., 2007; Albuquerque et al., 2012).

Wood is exploited throughout the year in the Brazilian Caatinga; however, its extraction increases significantly in the months that make up the dry period (Figueirôa et al., 2006; Albuquerque et al., 2012). Among other factors, water scarcity restricts agriculture and livestock activities during this period, thus evidencing the resources (wood) in the Caatinga landscape, making them a source of subsistence for communities until the rainy season (Araújo et al., 2007; Albuquerque et al., 2012). This impacts on the structure of tree communities (Araújo et al., 2007), as well as gradually decreases the wealth of the region's wood and carbon stocks (Pan et al., 2011; Albuquerque et al., 2012).

These types of pressure generate changes at the ecosystem level, but also at a specific level in the functional traits of tree species, such as in the anatomical structure of the wood (Carlquist, 2010; Baas \& Wheeler, 2011; Reich, 2014). These changes present latitudinal and pluviometric patterns, and are used as a support to define the main climatic regions of the globe (Zuidema et al., 2013). Extreme anatomical variations are evidence of trade-offs between the mechanical stress of the wood and the hydraulic architecture (Pineda-García et al., 2015; Gleason et al., 2016), and in some cases are explained in up to $92 \%$ by the changes in the climate (Roque et al., 2007). Conduction and storage structures are the main functional characters of wood, responsible for maintaining the physiology of trees under water stress (Pineda-García et al., 2015), and make up the functional models of these taxa (Zanne et al., 2010).

In this sense, understanding the anatomical arrangement of the wood assists in determining the possible causes of stress, whether they are environmental or anthropic (Figueirôa et al., 2006; Albuquerque et al., 2012; Anderegg \& Meinzer, 2015), as well as in the framework of their potential use (Benites et al., 2015; Brand et al., 2016) and proper management and conservation (Albuquerque et al., 2012; Santos et al., 2014).

In this way, the present work aimed to describe and quantify the wood anatomy of four common tree species in Caatinga regions of the state of Sergipe, Brazil, in order to verify the influence of environmental conditions on the anatomical characters of these species, to describe their organization in functional groups, and to determine its proper use, handling and conservation.

\section{MATERIAL AND METHODS}

\subsection{Study area}

This study was carried out in two sites: (Site 1) the conservation unit Grota do Angico Natural Monument, located in the northwest of Sergipe state on the São Francisco River ( $9^{\circ} 41^{\prime}$ S $38^{\circ} 31^{\prime}$ 'W), in an area of 2,183 hectares of dry forest (Ferraz et al., 2013; Silva et al., 2013; SEMARH, 2016) (Figure 1); (Site 2) a remnant of Caatinga with preserved shrub-tree vegetation located to the north at São Pedro Farm $\left(10^{\circ} 02.266^{\prime}\right.$ S $\left.37^{\circ} 24.965^{\prime} \mathrm{W}\right)$, with 50 hectares and an average altitude of $168 \mathrm{~m}$ (Oliveira et al., 2013) (Figure 1).

The climate of the region is semi-arid, dry and hot, marked by a rainy season between April and July, and a dry season between August and December (Köppen, 1948). The total annual precipitation varies from 380 to $760 \mathrm{~mm}$ for Site 1 (Figure 2a), and between 300 and $700 \mathrm{~mm}$ for Site 2 (Figure 2b), as well as annual mean air temperature between 18 and $25^{\circ} \mathrm{C}$, and annual 
potential evapotranspiration greater than the annual precipitation in the two areas. The municipalities where the two study sites are located have a high degree of deforestation, and they have the highest number of drought events among the counties of Sergipe (Bomfim et al., 2002; Jungles et al., 2011).

\subsection{Selected species}

Considering floristic surveys (Ferraz et al., 2013; Silva et al., 2013) in Poço Redondo (Oliveira et al., 2013) and in Porto da Folha, four species of heliophyte habit were selected: Aspidosperma pyrifolium Mart.

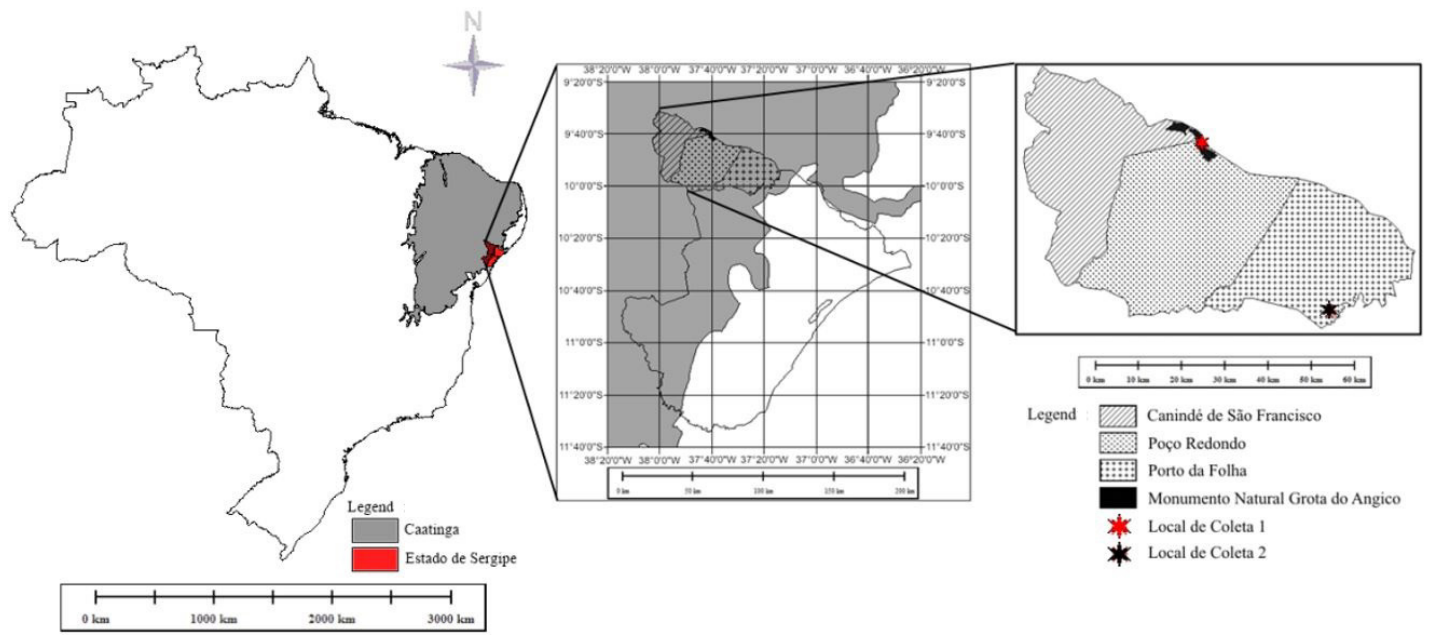

Figure 1. Study sites: Natural Monument Conservation Unit of Angico Grota (light star), municipalities of Canindé do São Francisco and Poço Redondo (S1); Fragment of Caatinga (dark star), municipality of Porto da Folha (S2), Sergipe state, Brazil.
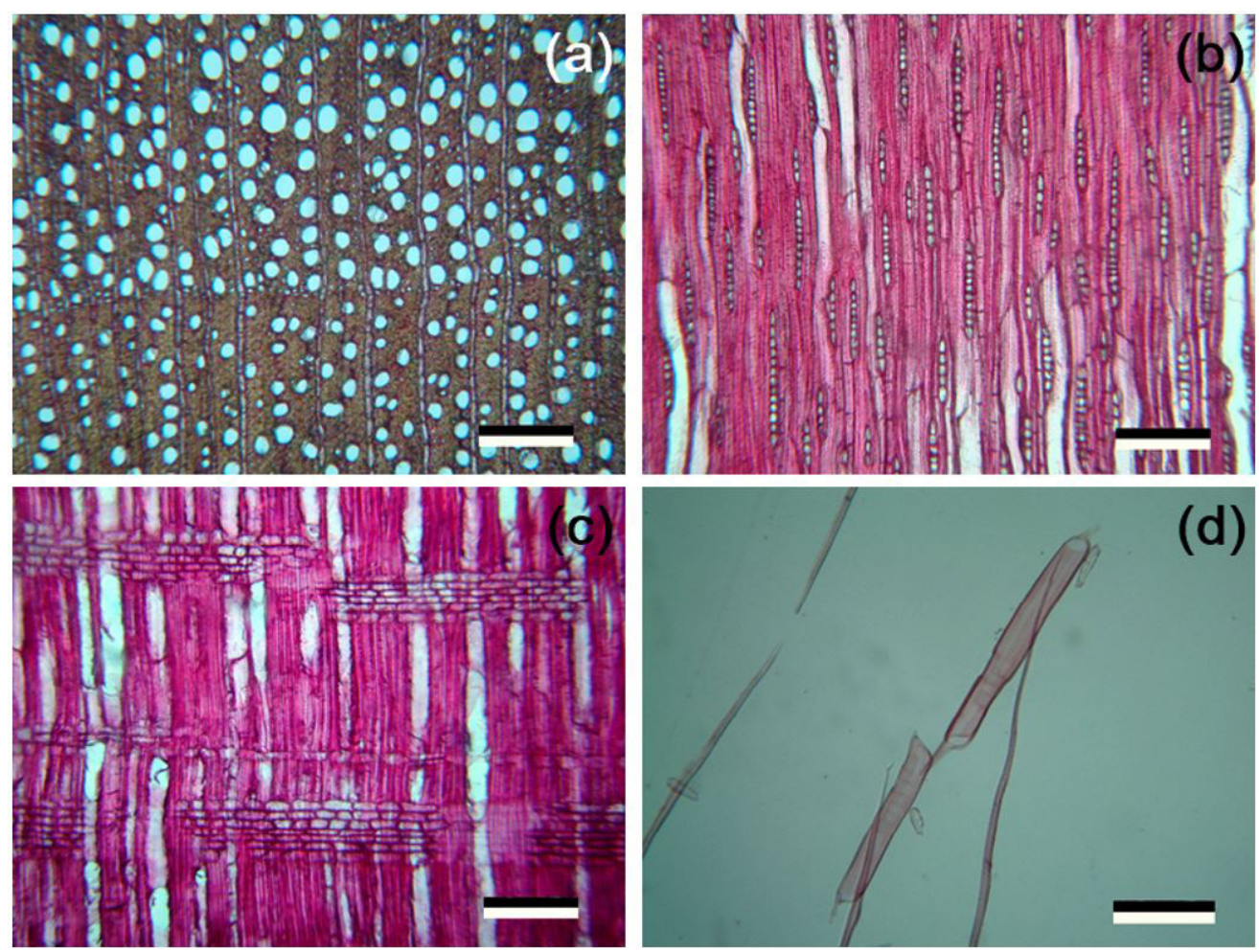

Figure 2. Histological sections of the A. pyrifolum wood collected in site 1 (S1) and site 2 (S2), Sergipe state, Brazil: (a) transversal plane, bar; (b) tangential longitudinal plane; (c) radial longitudinal; (d) macerated; Bar $=200 \mu \mathrm{m}$. 
(Apocynaceae), pioneering and deciduous; Libidibia ferrea (Mart. Ex Tul.) L. P. Queiroz (Fabaceae), secondary and semi-deciduous; Tabebuia aurea (Silva Manso) Benth. \& Hook. F. S. ex. Moore (Bignoniaceae), early secondary and semi-deciduous; and Ziziphus joazeiro Mart. (Rhamnaceae), pioneering and evergreen. These occur in both locations having high ecological and economic relevance for the region (Gandolfi et al., 1995; Carvalho et al., 2012; Andrade et al., 2015), and represent the growth dynamics of the Caatinga in Sergipe.

\subsection{Wood anatomical data collection}

Six subjects were randomly set for each species at each study site during the rainy season with wood samples being removed using a motorized core (Sthil BT45) (in trees with a diameter at breast height - DBH greater than $130 \mathrm{~cm}$ ). Three samples of each specimen were collected for anatomical analyzes for a total of six individuals per species at each study site, with all samples containing heartwood, sapwood and bark. These were packed in paper bags and then dried in a refrigerator at $-6^{\circ} \mathrm{C}$ at the Laboratory of Vegetable Anatomy and Dendroecology of the Federal University of Sergipe. Circumference at breast height (C.B.H.) of the trees was measured with tape, then diameter at breast height (D.B.H.) was calculated and the geographical coordinates were recorded for each individual.

\subsection{Environmental data collection}

The regional climatic data used in the analyzes were collected from the data platform of the National Institute of Meteorology (INMET), the Agrometeorological Monitoring System of Embrapa (AGRITEMPO), and the state platforms of each study Site. The values obtained for the environmental variables were adequate according to calculations of the platform WorldClim 2017 (WorldClim, 2017), where the regional values were standardized according to the 19 environmental layers (Bio's) of this platform. The most important environmental layers were submitted to statistical analyses with the anatomical data of the wood in order to observe the species' responses to the climate.

\subsection{Biological analyses}

For the anatomical analyses, the sapwood samples of each species were collected close to the shell in cubes of $2 \mathrm{~cm}^{3}$, and softened in water/glycerin solution (3:1). They were then sectioned in the three anatomical planes (transversal, tangential and radial), and 30 sections of each plane of each specimen were removed. Samples were clarified with sodium hypochlorite (20\%), dehydrated in an alcoholic series (30-50\%) and stained with alcoholic Safranin (1\%) (Johansen, 1940). The chemical maceration of each sample stained (Brown, 1919) with aqueous Safranin (1\%) was also obtained, and the anatomical elements were visualized separately. The tissues were visualized using a Bioval microscope under transmitted light at $40 \times, 100 \times$ and $400 \times$ magnification and photographed with a digital camera attached to the microscope. Characterization of the anatomical elements was performed according to the rules of the International Association of Wood Anatomists (IAWA) (Wheeler et al., 1989), and its measurement was carried out using the ImagePro-plus program (version 4.5.0.29 for Windows) (with an accuracy of $0.01 \mathrm{~mm}$ ).

The vessels' frequency per $\mathrm{mm}^{2}(\mathrm{VF})$, ray frequency (RF) $(\mathrm{mm})$, vessel diameter $(\mathrm{VD})(10$ per cut) $(\mu \mathrm{m})$, vessel area (VA) (10 per cut) $\left(\mu \mathrm{m}^{3}\right)$, ray height $(\mathrm{RH})$ (10 per cut) $(\mu \mathrm{m})$, ray width $(\mathrm{RW})(10$ per cut $)(\mu \mathrm{m})$, fiber length (FL) (30 measures) $(\mathrm{mm})$, fiber wall thickness (FWT) (30 measures) $(\mu \mathrm{m})$, and fiber lumen thickness (FLT) (30 measures) $(\mu \mathrm{m})$ were measured for each section. The following were also calculated: vulnerability index (VI), wood mesomorphism index (MI) (Carlquist, 1977), wall thickness (WT), wall fraction (WF), flexibility coefficient (FC), and Runkel index (RI) (30 measures for all) (Runkel, 1952). In total, 2,340 measurements were made per sample and 28,080 per species.

\subsection{Statistical analyses}

The results of the four species in both study sites were submitted to the Shapiro-Wilk normality test followed by the t-test for comparison of the means and evaluation of possible differences in the responses between the studied sites. The anatomical data of the taxa along with the environmental data were staggered (by deviations from the means in units of standard deviation) and submitted to principal component analysis (PCA) (under correlation matrix between groups) in order to consider the influence on the functional anatomical features of the trees. A Cluster analysis (in paired groups under the distance of Manhattan) and clustering by 
$\mathrm{K}$-means were performed in order to determine the relationship of the species' biological responses. Next, the values of the three more explanatory environmental variables were compared to the anatomical data from generalized linear model (GLM) tests in order to elucidate the possible environmental influence of each variable on the samples. The anatomical values significantly influenced by environmental variables were subsequently submitted to the Pearson correlation ( $r$ ) in order to observe the type of relationship between the data and the climate (direct or antagonistic). All analyses were performed using R 3.2.1. and Past $2.17 \mathrm{c}$ software programs.

\section{RESULTS}

\subsection{Anatomical description of wood}

\subsubsection{Aspidosperma pyrifolium}

\subsubsection{Macroscopic analysis}

Heartwood is distinct from sapwood by its coloration, as heartwood is dark brown and sapwood is beige; it exhibits moderate brightness, bitter taste and imperceptible scent, and is a hard wood to cut with direct grains, a fine texture and growth layers that are distinct to the naked eye. Its axial parenchyma is only visible under lens; its rays are invisible to the naked eye, very thin to thin, and numerous; its vessels are only visible under lens, very small to small, very numerous to numerous, of diffuse porosity and in radial arrangement without obstruction; it has low rays, only visible in the tangential plane under a lens, not stratified, and little contrasted in the radial plane.

\subsubsection{Microscopic analysis}

Vessels: diffuse porosity, predominantly solitary, radially grouped, rarely twinned or multiple, very small, very frequent, circular in shape, appendices at one or both ends, or completely absent (Figure $2 \mathrm{a}$ and $2 \mathrm{~d}$ ). They have a simple oblique perforation plate, which is small with alternating and bordered intervessel pits (Figure 2d).

Growth ring: distinct, with occurrence of fiber flattening and presence of uniseriate marginal parenchyma line; the growth layer is also characterized by vessel size and clustering, where vessels are more clustered and larger at the beginning of the growth layer, and less clustered and smaller at their end (Figure 2a).
Axial parenchyma: scarce paratracheal (Figure 2a).

Radial parenchyma: non-stratified, predominantly unisseriate with the occurrence of multiseriate of up to three cells, very fine, extremely low, very numerous, with the presence of substances in its interior; heterogeneous, poorly contrasted, with procumbent cells and presence of substances (Figure $2 \mathrm{~b}$ and $2 \mathrm{c}$ ).

Fibers: medium-length, narrow, septa-free, thick-walled libriformes with reduced lumen, numerous simple points evident throughout the fibers (Figure 2d).

\subsubsection{Ziziphus joazeiro}

\subsubsection{Macroscopic analysis}

Heartwood is distinct from the sapwood by coloration, as the heartwood is black and the sapwood is yellow; it exhibits moderate brightness and imperceptible scent, is an intermediate-soft wood to the cut with direct grain, a fine texture, with the axial parenchyma and the growth layers being indistinct to the naked eye; its rays are invisible to the naked eye, very thin to thin, numerous; its pores are visible to the naked eye, small to medium, very infrequent and of diffuse porosity in radial arrangement with possible obstruction; it has low rays which are only visible in the tangential plane under a lens, not stratified, and little contrasted in the radial plane.

\subsubsection{Microscopic analysis}

Vessels: are not uniform, diffuse array grouped tangentially, are mostly solitary in multiples of 2-6 and in clusters (up to 3 ), rarely solitary, and eventually blocked by tyloses. They have medium length, are very numerous, very short and circular in shape with no appendages, or rarely short and may have appendages on one end (Figure $3 \mathrm{a}$ and $3 \mathrm{~d}$ ). They have simple oblique or straight perforation plates and the intervessel points are small, alternate and bordered (Figure 3d).

Growth ring: distinct, semi-porous ring with occurrence of fiber flattening and presence of a narrow line of unisseriate marginal parenchyma (Figure 3a).

Axial parenchyma: scarce paratracheal and apotracheal in lines. It has a marginal formation parallel to fiber flattening next to the growth layer (Figure 4a).

Radial parenchyma: non-stratified, predominantly multiseriate, occurring from 2 to 4 cells, fine, extremely low, very numerous and with the presence of crystals in its interior; heterogenous, poorly contrasted and with procumbent cells (Figure $3 \mathrm{~b}$ and $3 \mathrm{c}$ ). 

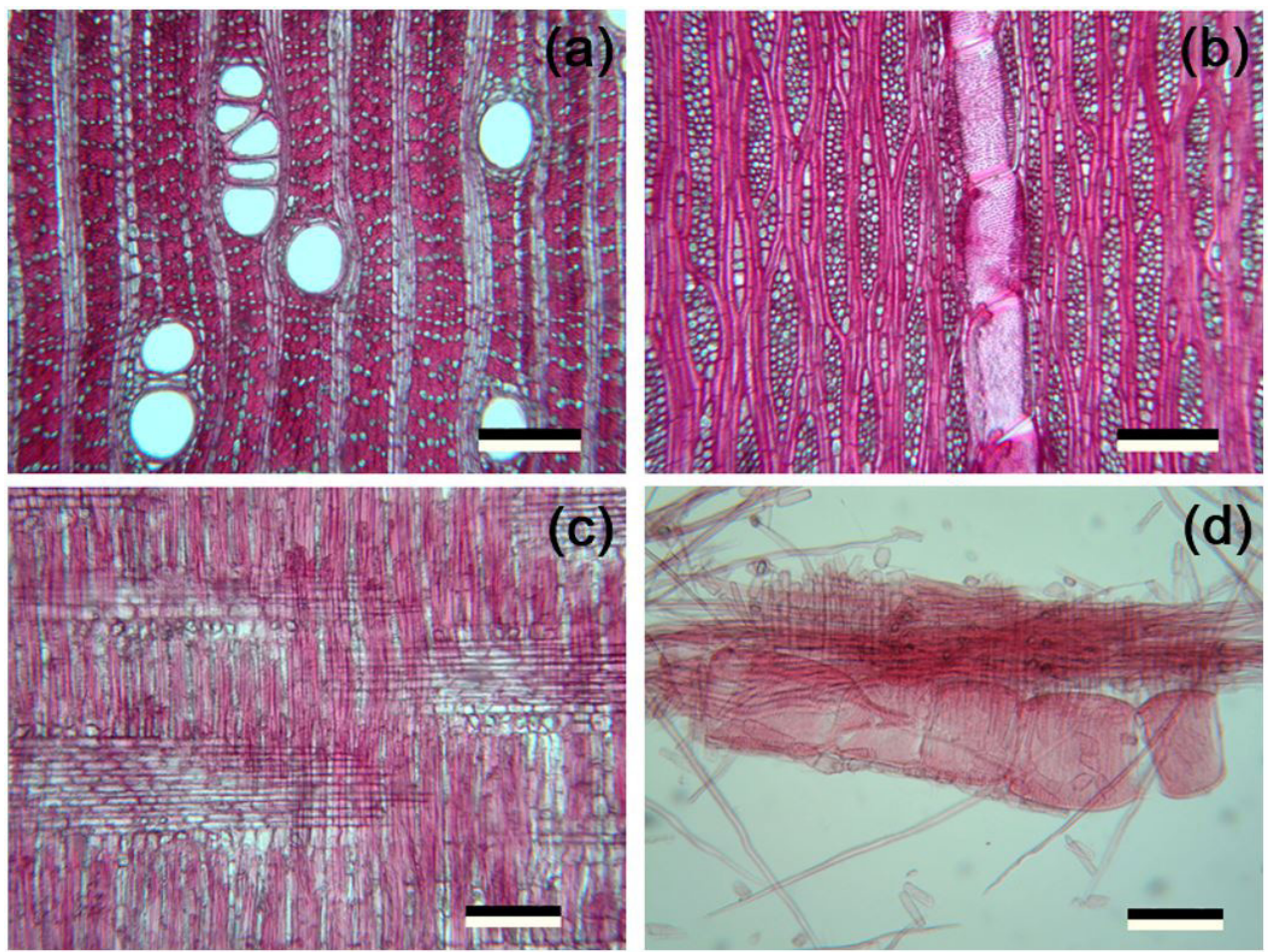

Figure 3. Histological sections of the Z. joazeiro wood collected in site 1 (S1) and site 2 (S2), Sergipe state, Brazil: (a) transversal plane, bar; (b) tangential longitudinal plane; (c) radial longitudinal; (d) macerated; Bar $=200 \mu \mathrm{m}$.
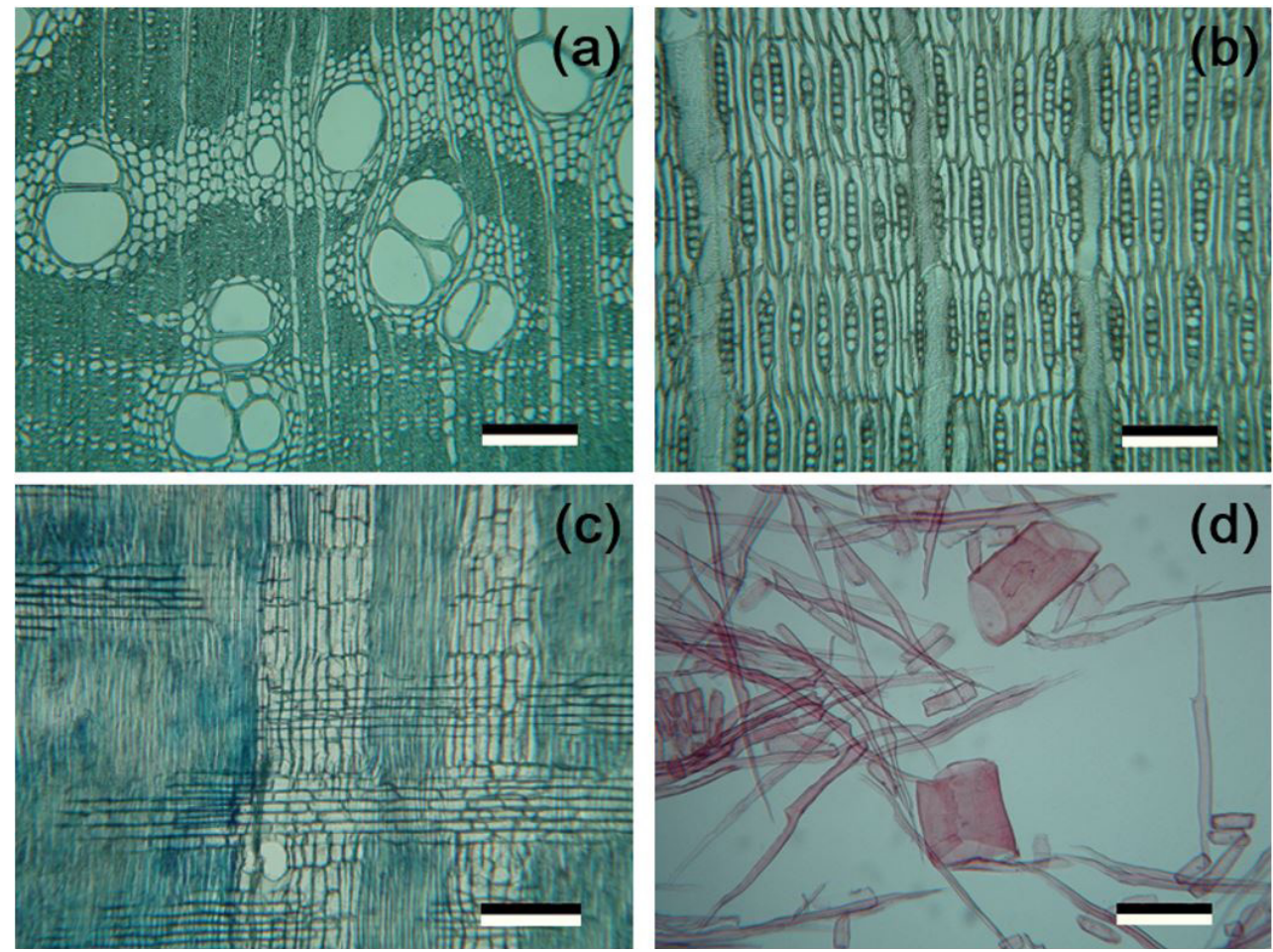

Figure 4. Histological sections of the T. aurea wood collected in site 1 (S1) and site 2 (S2), Sergipe state, Brazil: (a) transversal plane, bar; (b) tangential longitudinal plane; (c) radial longitudinal; (d) macerated; Bar $=200 \mu \mathrm{m}$. 
Fibers: Libriform, moderately short in length, narrow, with very thick walls and reduced lumen (Figure $3 \mathrm{~d}$ ).

\subsubsection{Tabebuia aurea}

\subsubsection{Macroscopic analysis}

Heartwood is distinct from sapwood by coloration, as the heartwood is dark brown and sapwood is light brown; it has a moderate brightness and imperceptible odor, soft cutting wood, irregular grain, fine texture, axial parenchyma and growth layers are distinguished by the naked eye; its rays are invisible to the naked eye, very fine, very numerous; its pores are visible to the naked eye, medium, few, diffuse porosity and in radial arrangement with possible obstruction; it has low rays which are only visible in the tangential plane under a lens, moderately stratified, and little contrasted in the radial plane.

\subsubsection{Microscopic analysis}

Vessels: arranged in semiporous rings, grouped tangentially or radially, are mostly multiples of 2-8 and in bunches (up to 6), are rarely solitary and eventually obstructed by tyloses. They are large in diameter, few in number, very short and circular in shape, absent in appendages, or they may rarely have short appendages at one end (Figure $4 \mathrm{a}$ and $4 \mathrm{~d}$ ). They have simple oblique or straight perforation plates, and the intervessel points are small, alternating and bordered (Figure 4d).

Growth ring: distinct with occurrence of fiber flattening and presence of unisseriate marginal parenchyma line (Figure 4a).

Axial parenchyma: paratracheal, vasicentric aliform of angular extension, confluent. It has marginal formation parallel to the growth layer, and may or may not occur in ring formation (Figure 4a).

Radial parenchyma: partially laminated with a predominantly multiseriate wavy stratification, occurring from 2 to 5 cells, very thin, extremely low, and very numerous; heterogeneous, poorly contrasted and with procumbent cells (Figure $4 \mathrm{~b}$ and $4 \mathrm{c}$ ).

Fibers: Libriform, moderately short in length, narrow and thick-walled (Figure 4d).

\subsubsection{Libidibia ferrea}

\subsubsection{Macroscopic analysis}

Heartwood is distinct from sapwood by coloration, as the heartwood is black and the sapwood is yellow; presents moderate brightness and imperceptible scent, it is a hard wood to cut with direct grain and a fine texture, with axial parenchyma and growth layers being distinct to the naked eye; its rays are invisible to the naked eye, very thin to thin, numerous; its pores are only visible under a lens, small, numerous, and of diffuse porosity in radial arrangement with possible obstruction; it has low rays, only visible in the tangential plane under a lens, moderately stratified, and little contrasted in the radial plane.

Vessels: their arrangement is in semiporous rings, tangentially grouped, are mostly multiples of 2-4 and in bunches (up to 6), rarely solitary, and eventually obstructed by tiloses. They are medium, not very numerous, very short and circular in shape with absent appendages, or they may rarely present short appendages at one end (Figure $5 \mathrm{a}$ and $5 \mathrm{~d}$ ). They have simple (foraminated) oblique or straight perforation plates, and the intervessel points are small, alternate and bordered (Figure 5d).

Growth ring: distinct, with marginal parenchyma line uniseriate together with thickening in the fiber walls in the latewood; the growth layer is also characterized by vessel size and clustering, where vessels are less clustered and larger at the beginning of the growth layer, and less clustered and smaller at their end (Figure 5a).

Axial parenchyma: paratracheal, vasocentric aliform of angular extent, confluent, and with the presence of amyloplasts. It has a marginal formation parallel to the growth layer, and may or may not occur in the formation of the rings (Figure 5a).

Radial parenchyma: partially laminated with predominantly multiseriate undulating stratification, occurring from 2 to 4 cells, thin, extremely low, numerous, and with the presence of substances (starch) and crystals in its interior; heterogeneous, poorly contrasted and with procumbent cells (Figure $5 b$ and $5 c$ ).

Fibers: Libriform, medium length, narrow, with very thick walls and reduced lumen (Figure 5a).

\subsection{Anatomical variation of wood}

The anatomical elements evaluated among the four species had significant variations with emphasis on frequency, diameter, length and area of vessels, fiber length, vulnerability index, mesomorphism and Runkel (Table 1). The mean anatomical values of the individuals of each species in the two study sites also varied, suggesting different responses among the sites, with significant values (Table 1). 

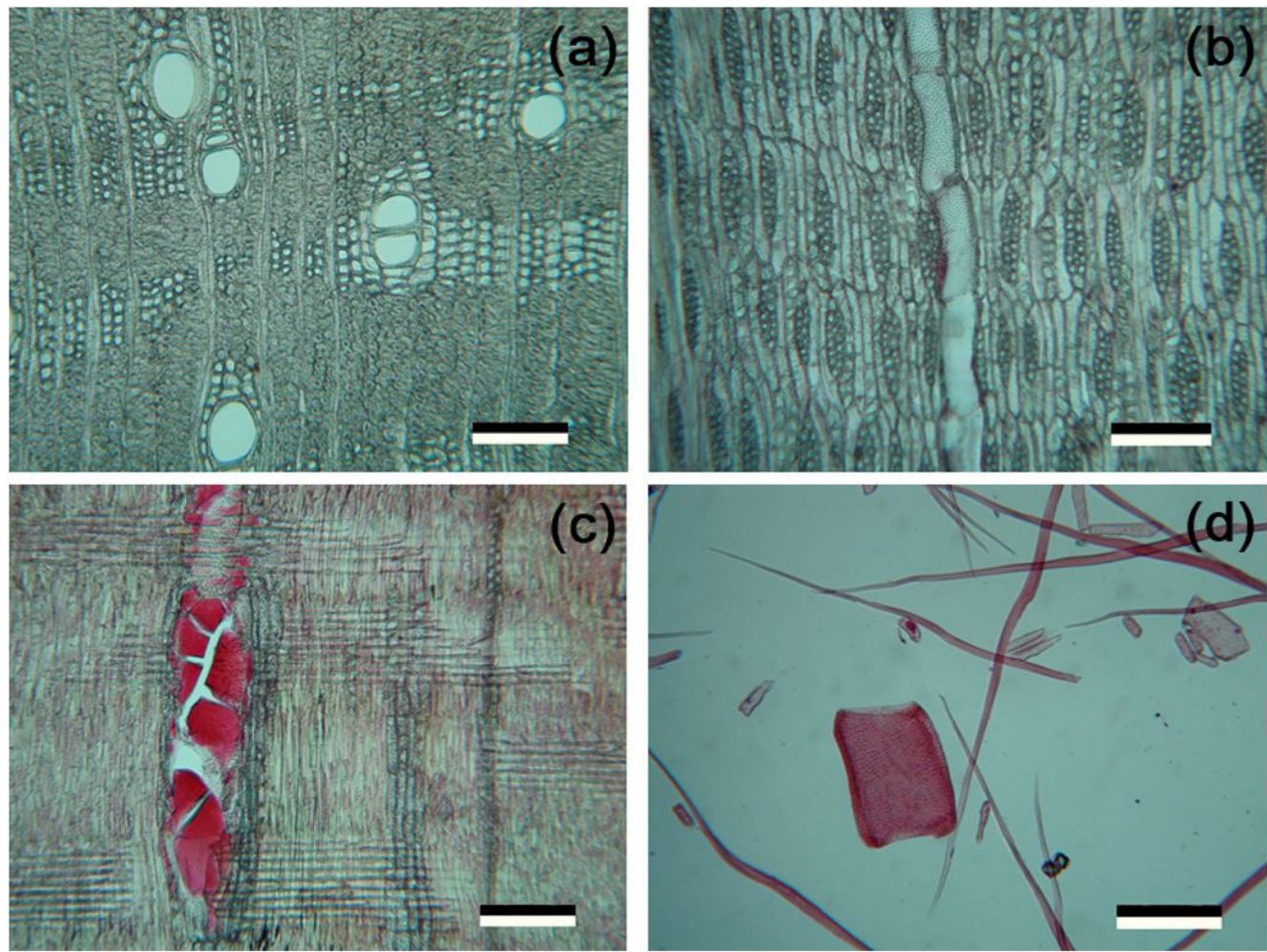

Figure 5. Histological sections of the L. ferrea wood collected in site 1 (S1) and site 2 (S2), Sergipe state, Brazil: (a) transversal plane, bar; (b) tangential longitudinal plane; (c) radial longitudinal; (d) macerated; Bar $=200 \mu \mathrm{m}$.

Table 1. Mean values of the anatomical elements of A. pyrifolium, Z. joazeiro, T. aurea, and L. ferrea, collected in site 1 (S1) and site 2 (S2), Sergipe state, Brazil. $\pm=$ standard deviation; Bold values $=$ significant at $\mathrm{p}<0.05 \mathrm{From}$ the comparison between sites by the T-test.

\begin{tabular}{|c|c|c|c|c|c|c|c|c|}
\hline & $\begin{array}{c}\text { A. } \\
\text { pyrifolium_SI }\end{array}$ & $\begin{array}{c}\text { A. } \\
\text { pyrifolium_S2 }\end{array}$ & $\begin{array}{c}Z . \\
\text { joazeiro_S1 }\end{array}$ & $\begin{array}{c}Z . \\
\text { joazeiro_S2 }\end{array}$ & $\begin{array}{c}T . \\
\text { aurea_S1 }\end{array}$ & $\begin{array}{c}T . \\
\text { aurea_S2 }\end{array}$ & $\begin{array}{c}\text { L. } \\
\text { ferrea_S1 }\end{array}$ & $\begin{array}{c}L . \\
\text { ferrea_S2 }\end{array}$ \\
\hline VF & $4 \pm 16.78$ & $211.34 \pm 12.78$ & $1+125$ & +149 & $6+145$ & $4+03$ & $72 \pm 2.12$ & $33+1-1$ \\
\hline RF & $19+073$ & $105+020$ & 6 & & & & & \\
\hline VD & & 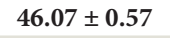 & & & & & & \\
\hline VL & & 0 & 55 & & & & & \\
\hline VA & & & & & & & & \\
\hline RH & $5+15$ & 1 & 0 & 1 & 2 & & & \\
\hline RW & $16.08 \pm 0$ & $16.24 \pm 0$ & 8 & 3 & 1 & & 37.5 & 0.6 \\
\hline FL & & & & & & $0-1$ & (5) & 1.00 \\
\hline & & & & & & & & \\
\hline & & & & & & & & \\
\hline V & $5 \pm 0$ & & $.59 \pm 2.75$ & \pm 2 & \pm 3.02 & & 18 & $6 \pm 3$ \\
\hline M & +0 & +0 & te & 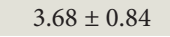 & +0 & $1+8,-2$ & + & + \\
\hline $\mathbf{W}^{\prime}$ & $7 \pm 0$ & $5+0$ & $0.51 \pm 0.04$ & + & $3+$ & \pm 0 & $79 \pm$ & 6 \\
\hline WF & 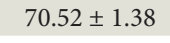 & +1 & 010 & $5 \pm 1.21$ & $2 \pm 2.20$ & 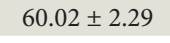 & $10.13+4$ & $1 / .42 \pm 2$ \\
\hline CF & $29.48 \pm 1.38$ & $66 \pm 3.12$ & $29.02 \pm 0$ & $07 \pm 1.27$ & $38 \pm 2$ & $98 \pm 2$ & $23.27 \pm 4$ & $22.58 \pm 2$ \\
\hline $\mathbf{R}$ & 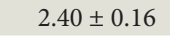 & & & & & & ? & 然 \\
\hline 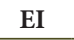 & $39 \pm 5.21$ & $63 \pm 5.87$ & $16 \pm 7.83$ & $.51 \pm 7.35$ & $.72 \pm 4.41$ & $0.10 \perp 0.2 J$ & $51.11 \pm 5.62$ & 61 \\
\hline
\end{tabular}

$\mathbf{V F}=$ vessel frequency $\left(\mathrm{mm}^{2}\right) ; \mathbf{R F}=$ ray frequency $(\mathrm{mm}) ; \mathbf{V D}=$ Vessel diameter $(\mu \mathrm{m}) ; \mathbf{V L}=$ vessel length $(\mu \mathrm{m}) ; \mathbf{V A}=$ vessel area $\left(\mu \mathrm{m}^{3}\right) ;$ $\mathbf{R H}=$ ray height $(\mu \mathrm{m}) ; \mathbf{R W}=$ ray width $(\mu \mathrm{m}) ; \mathbf{F L}=$ fiber length $(\mu \mathrm{m}) ; \mathbf{F W T}=$ fiber wall thickness $(\mu \mathrm{m}) ; \mathbf{F L T}=$ fiber lumen thickness $(\mu \mathrm{m}) ; \mathbf{V I}=$ vulnerability index; $\mathbf{M I}=$ mesomorphism index; $\mathbf{W T}=$ wall thickness; $\mathbf{W F}=$ wall fraction; $\mathbf{C F}=$ coefficient of flexibility; $\mathbf{R I}=$ Runkel index; $\mathbf{E I}=$ enfeltrament index. 
When weighted on the environmental variables by PCA, the anatomical data of the wood explained 93\% of the values in the first two axes (axis 1 - 73\%, axis $2-20 \%$ ), which shows its strong relation with the climate and the different strategies used by the taxa for water use in the wood (Figure 6). The cluster analysis (Cluster and K-means) similarly revealed significant levels of organization between the groups for the anatomical values of the wood (0.968) (Figure 6). There was then a complete distinction between the

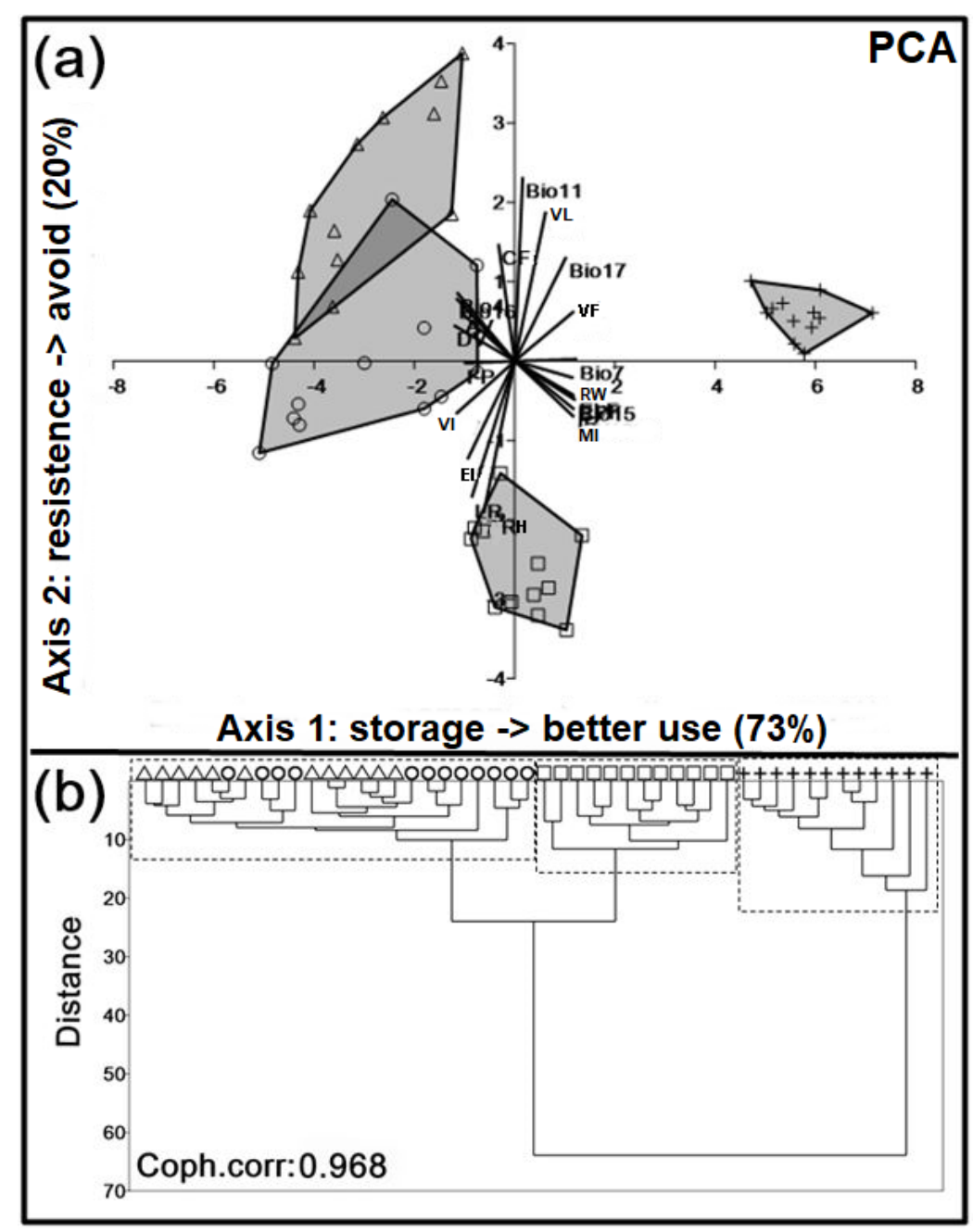

Figure 6. Principal components analysis (PCA) (a) and clustering (b) for the anatomical characters of the wood of four tree species of Caatinga in relation to six environmental variables of temperature and precipitation in (S1) and (S2); + = A. pyrifolium; $\square=Z$. joazeiro; $\Delta=T$. aurea $; \circ=L$. ferrea; Coph.corr $=$ coefficient of cophonetic correlation. VF = vessel frequency $\left(\mathrm{mm}^{2}\right) ; \mathbf{R F}=$ ray frequency $(\mathrm{mm}) ; \mathbf{V D}=\operatorname{Vessel}$ diameter $(\mu \mathrm{m}) ; \mathbf{V L}=$ vessel length $(\mu \mathrm{m}) ; \mathbf{V A}=$ vessel area $\left(\mu \mathrm{m}^{3}\right) ; \mathbf{R H}=$ ray height $(\mu \mathrm{m}) ; \mathbf{R W}=$ ray width $(\mu \mathrm{m}) ; \mathbf{F L}=$ fiber length $(\mu \mathrm{m}) ; \mathbf{F W T}=$ fiber wall thickness $(\mu \mathrm{m})$; FLT $=$ fiber lumen thickness $(\mu \mathrm{m}) ; \mathbf{V I}=$ vulnerability index; $\mathbf{M I}=$ mesomorphism index; WT = wall thickness; WF = wall fraction; $\mathbf{C F}=$ coefficient of flexibility; $\mathbf{R I}=$ Runkel index; $\mathbf{E I}=$ enfeltrament index; Bio1 = Annual Mean Temperature; Bio2 = Mean Diurnal Range (Mean of monthly (max temp - min temp)); Bio3 = Isothermality $\left(\right.$ Bio2/Bio7) $\left({ }^{\star} 100\right) ; \mathbf{B i o 4}=$ Temperature Seasonality $\left(\right.$ standard deviation $\left.{ }^{\star} 100\right) ; \mathbf{B i o 5}=$ Max Temperature of Warmest Month; Bio6 = Min Temperature of Coldest Month; Bio7 = Temperature Annual Range (Bio5-Bio6); Bio8 = Mean Temperature of Wettest Quarter; Bio9 = Mean Temperature of Driest Quarter; Bio10 = Mean Temperature of Warmest Quarter; Bio11 = Mean Temperature of Coldest Quarter; Bio12= Annual Precipitation; Bio13 = Precipitation of Wettest Month; Bio14 $=$ Precipitation of Driest Month; Bio15 $=$ Precipitation Seasonality (Coefficient of Variation); Bio16 = Precipitation of Wettest Quarter; Bio17 = Precipitation of Driest Quarter; Bio18 = Precipitation of Warmest Quarter; Bio19 = Precipitation of Coldest Quarter. 
individuals of $A$. pyrifolium and $Z$. joazeiro in relation to T. aurea and L. ferrea (Figure 6) which, although appearing separated, presented some individuals merged in the grouping between the two taxa given their structural similarities (elements and vessel and axial parenchyma) (Figure 4 and 5).

In this sense, six environmental variables showed influence on the wood anatomy of the four species, namely: the seasonal variation of temperature (SVT), the mean annual temperature (MAT), mean temperature in the coldest period (MTC), seasonal variation of precipitation (SVP), wet (WP) and dry precipitation (DP) (Table 2).

\subsection{Environmental influences on wood structure}

Overall GLM's showed a greater influence of mean annual temperature on the anatomical structures of A. pyrifolium and Z. joazeiro (Table 2). T. aurea showed a strong relation of its anatomy with the precipitation that occurs in the dry period (Table 2), while L. ferrea revealed a proportional relation between the three environmental variables to which it was compared (seasonality of temperature, seasonal precipitation and wet period) (Table 2), all with high numbers of anatomical characters related to variations in the environment.

Pearson (r) correlations corroborated the influences shown by GLM (Table 2). In this sense, it is possible to highlight the relation between annual mean temperature and fiber length of A. pyrifolium (+95\%) (Table 2) and rainfall in the wet period on its vessel diameter (+91\%) (Table 2). Similarly, rainfall in the wet period had an influence on the frequency of $Z$. joazeiro rays (-93\%) (Table 2), as well as on their wall thickness (-87\%) (Table 2). Both taxa also showed strong relationships between the Runkel index and the annual average temperature $(+93 \%$ in A. pyrifolium and $-91 \%$ in $Z$. joazeiro), which points to the high influence of this variable on structure and quality wood of these species.

Among the correlations which occurred between precipitation in $T$. aurea during the dry period, the frequency of vessels $(+86 \%)$ (Table 2$)$, the fiber wall thickness (+76\%), and the flexibility coefficient $(+77 \%)$

Table 2. Generalized linear models (GLM) and Pearson (r) correlations between the anatomical data of the four Caatinga tree species and environmental variables of the Brazilian Northeast.

\begin{tabular}{|c|c|c|c|c|c|c|c|c|c|c|c|c|}
\hline & \multicolumn{3}{|c|}{ Aspidosperma pyrifolium } & \multicolumn{3}{|c|}{ Ziziphus joazeiro } & \multicolumn{3}{|c|}{ Tabebuia aurea } & \multicolumn{3}{|c|}{ Libidibia ferrea } \\
\hline & SVT & MAT & WP & SVT & MAT & WP & SVT & MTC & DP & MAT & SVP & WP \\
\hline VF & $0.86^{\star}$ & -0. & -0.24 & 0.16 & - & -0.47 & $3^{*}$ & 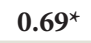 & 0 & 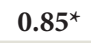 & 0. & $-0.80^{*}$ \\
\hline RF & $-0.41_{-}$ & & 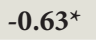 & 0.1 & & -0.9 & - & * & & $1^{*}$ & 0. & -0.57 \\
\hline VD & -0.46 & $-C$ & 21 & 0.29 & & 0.27 & .49 & * & 0 & $5^{*}$ & -0.6 & 0.52 \\
\hline VI & $-0.82^{*}$ & & -0.02 & 0.5 & & 0.19 & $t_{-}$ & + & 0 & * & & $92^{*}$ \\
\hline VA & -0.7 & & 4 & .4 & 0.25 & $-c$ & 3 & & 1 & & & -0 \\
\hline RH & - & & $5_{-}$ & -0.46 & - & -0.40 & -0.37 & -0 . & - & & & $.75^{\star}$ \\
\hline RW & -0.5 & & 5 & 0.21 & - & 0. & 22 & $0.31_{-}$ & $7_{-}$ & $-0.50_{-}$ & -0. & 0.13 \\
\hline FL & -0.6 & & -0.5 & -0.19 & & -0.8 & 0.40 & 0.36 & 0. & $.79^{*}$ & 0.5 & $-0.91^{*}$ \\
\hline FWT & -0.6 & & -0.53 & -0.18 & & -0. & 49 & - & 0.70 & * & * & $-0.92^{\star}$ \\
\hline FLT & -0.6 & & $-0.52 \_$ & -0.18 & & -0. & 48 & 0.4 & 0.6 & 0.7 & & $-0.92^{\star}$ \\
\hline V & -0.6 & & -0 & -0 . & 0 & -0.5 & -0. & -0 & -0 & -0 & -0 . & 0.36 \\
\hline MI & $-0.61^{\star}$ & & $-0.51_{-}$ & -0.2 & & $-0.85^{\star}$ & -0.25 & -0.36 & -0.03 & 0.33 & 0.7 & $-0.63^{*}$ \\
\hline WT & $-0.60^{*}$ & 002 & $-0.52 \_$ & -0.18 & $0.88^{\star}$ & $-0.89^{\star}$ & 0.45 & 0.4 & $0.67^{\star}$ & $0.79^{*}$ & $0.99^{*}$ & $-0.92^{\star}$ \\
\hline WF & $0.74^{\star}$ & $-0.69^{*}$ & $0.19_{-}$ & 0.55 & $-0.60^{*}$ & $0.65^{\star}$ & $0.74^{*}$ & 0.7 & $0.65^{\star}$ & 0.02 & -0.58 & 0.44 \\
\hline CF & 0.32 & -0.03 & $0.18 \_$ & 0.24 & $-0.12 \_$ & 0.49 & $0.82^{\star}$ & $0.78^{\star}$ & $0.77^{\star}$ & $0.64^{\star}$ & 0.36 & -0.35 \\
\hline RI & $-0.60^{*}$ & $0.93^{\star}$ & -0.54 & -0.15 & $0.88^{\star}$ & $-0.91^{\star}$ & 0.44 & 0.42 & $0.66^{*}$ & $0.81^{\star}$ & $0.98^{\star}$ & $-0.91^{\star}$ \\
\hline EI & $-0.69^{\star}$ & 0.02 & 0.44 & -0.01 & $-0.43_{-}$ & $0.47_{-}$ & $-0.68^{\star}$ & $-0.63^{\star}$ & $-0.65^{\star}$ & -0.05 & -0.27 & 0.46 \\
\hline
\end{tabular}

$\mathbf{V F}=$ vessel frequency $\left(\mathrm{mm}^{2}\right) ; \mathbf{R F}=$ ray frequency $(\mathrm{mm}) ; \mathbf{V D}=$ Vessel diameter $(\mu \mathrm{m}) ; \mathbf{V L}=$ vessel length $(\mu \mathrm{m}) ; \mathbf{V A}=$ vessel area $\left(\mu \mathrm{m}^{3}\right) ; \mathbf{R H}=$ ray height $(\mu \mathrm{m}) ; \mathbf{R W}=$ ray width $(\mu \mathrm{m}) ; \mathbf{F L}=$ fiber length $(\mu \mathrm{m}) ; \mathbf{F W T}=$ fiber wall thickness $(\mu \mathrm{m}) ; \mathbf{F L T}=$ fiber lumen thickness $(\mu \mathrm{m}) ; \mathbf{V I}=$ vulnerability index; $\mathbf{M I}=$ mesomorphism index; $\mathbf{W T}=$ wall thickness; $\mathbf{W F}=$ wall fraction; $\mathbf{C F}=$ coefficient of flexibility; RI = Runkel index; EI = enfeltrament index; SVT = seasonal variation of temperature; $\mathbf{M A T}$ = mean annual temperature; MTC = mean temperature in the coldest period; SVP = seasonal variation of precipitation; $\mathbf{W P}=$ wet precipitation; $\mathbf{D P}=$ dry precipitation; ${ }^{*}=$ GLM’s significant at $\mathrm{p}<0.05$; Values in bold $=r$ significant at $\mathrm{p}<0.05$. 
may be highlighted (Table 2). The most significant correlations in $L$. ferrea were the average annual temperature with the lightning frequency $(+94 \%)$ (Table 2), and the seasonal precipitation variation with fiber length (+99\%) and Runkel (-91\%) (Table 2). However, the environmental influences of annual mean temperature and precipitation events in different periods of the year were relevant in the wood structure of the evaluated species.

\section{DISCUSSION}

The qualitative characteristics of the wood generally did not change due to the environmental conditions; however, the quantitative characteristics showed strong relations with the variations in the environment and revealed the existence of three different functional groups between the species. Thus, these characteristics showed potential use for evaluating functional groups in a similar way to the results corroborated by other researches developed in dry forests of Mexico and rainy forests in Australia (Pineda-García et al., 2015; Apgaua et al., 2017). The variations observed herein between species in the two study sites also corroborate the heterogeneity of the Caatingas (Costa et al., 2015), as well as alert us to environmental influences on this plant formation, thereby reiterating the need for its management and conservation as highlighted by other authors (Albuquerque et al., 2012).

The anatomical structural organization of the secondary xylem of the four species showed at least three distinct functional groups (Figure 6). T. aurea and L. ferrea differed from their storage structures (group 1), while A. pyrifolium had higher hydraulic safety, mainly in the water conduction structures of the wood (vessel elements) (group 2), and Z. joazeiro for presenting intermediate characteristics between these two groups (group 3), which corroborates other studies of the genus (Anderegg \& Meinzer, 2015; Pineda-García et al., 2015; Gleason et al., 2016; Apgaua et al., 2017). The high proportion of parenchyma observed in the wood of T. aurea and L. ferrea, as well as of potting elements in A. pyrifolium, are characteristics which, according to Carlquist (2010) and Baas \& Wheeler (2011), refer to the specializations that followed different evolutionary paths and allowed the occurrence of angiosperms in many environments. The high frequency of vessel elements and their reduced caliber are also framed as characteristics common to pioneer species that survive in xeric environments (Baas \& Wheeler, 2011; Anderegg \& Meinzer, 2015). Regardless of the type of adaptation, it is possible to highlight that the anatomical structures of all evaluated species presented common specializations for survival in extreme environments (Carlquist, 2010; Baas \& Wheeler, 2011), as well as trade-offs between the best use of water or its storage, similar to that observed in other studies (Pineda-García et al., 2015; Gleason et al., 2016; Apgaua et al., 2017).

The observed relationships between the anatomical functional characters of the four species and the climatic conditions (Figure 6, Table 2) corroborate the hypothesis that different functional groups respond in a significant way to environmental variations, either under water conduction efficiency (axial and radial parenchyma) or wood support (fibers), as observed by Anderegg \& Meinzer (2015) Gleason et al. (2016) and Apgaua et al. (2017).

Among the functional groups formed by the four species, it was possible to observe that the anatomy of the wood was influenced by temperature and precipitation (A. pyrifolium), precipitation in the dry period (T. aurea), or by seasonal variations of precipitation ( $L$. ferrea); factors that act on the hydraulic conductivity (Anderegg \& Meinzer, 2015) and generate damage that can make these species vulnerable in the near future (Santos et al., 2014). According to Baas \& Wheeler (2011), the velocity of the effects generated by the changes in the climate inhibits the hydraulic and mechanical adaptive potential of the secondary xylem of the trees, which restricts their area of occurrence and consequently promotes impacts on the biodiversity of vascular plants. These effects are also capable of reducing the caliber of the potting elements, increasing the fibers density and disorganizing the parenchyma structures, which compromises the water balance as well as the whole photosynthetic process, and generates damage to the species' development (Baas \& Wheeler, 2011; Anderegg \& Meinzer, 2015). However, in an antagonistic way, $Z$. joazeiro did not show direct dependence of rainfall events, which suggests the existence of other types of adaptations, whether they be metabolic or root (Brunner et al., 2015), and allows the survival of this species in xeric environments.

The environmental influences highlighted for the anatomical characters were also observed in the wood quality indexes, mainly on the Runkel index (RI) (in A. pyrifolium, Z. joazeiro and L. ferrea) and 
the infiltration index (II) (in T. aurea), which warn of the impact of climate on wood quality (Carlquist, 2010; Baas \& Wheeler, 2011; Anderegg \& Meinzer, 2015; Gleason et al., 2016). In addition to environmental pressures, anthropic action may interfere with these relationships and aggravate their effect, since poor management of the timber waste/residue interferes with their quality and the survival of tree species (Figueirôa et al., 2006).

From the perspective wood use determined herein by the anatomical characters, it was possible to observe that the four species have mainly civil construction and energy use purposes, except for T. aurea, which presented quantitative characteristics (such as RI) in carpentry and paper production, but qualitatively had this last purpose discarded given the high presence of parenchyma structures (Runkel, 1952; Foelkel \& Barrichelo, 1975; Longui et al., 2009). The use of these species by human communities established in Caatinga areas has extrapolated the limits of their purposes (Silva et al., 2014), contributed to the reduction of vegetated areas (Araújo et al., 2007; Albuquerque et al., 2012) or stagnation in intermediate succession stages of the forests, as observed in Site 1 (Ferraz et al., 2013).

However, there is a need for actions focused on detailed research in Caatinga areas (Albuquerque et al., 2012), mainly in relation to the use of the resources coming from this vegetation (Araújo et al., 2007; Araújo, 2011), as well as the adequate management of timber resources, which may have its quality compromised by the climatic conditions, in addition to anthropic action (cutting regime) (Figueirôa et al., 2006; Brand et al., 2016).

\section{CONCLUSIONS}

The four species had their anatomical characteristics influenced by the Caatinga environmental conditions, mainly by the precipitation and temperature of the region.

There was the distinction of three functional groups in the wood anatomy of the four species, responding to different environmental variables.

From the observed anatomical characters, it is recommended that $A$. pyrifolium, $Z$. joazeiro and L. ferrea have their wood destined to civil construction or to energy use, and T. aurea to carpentry or in studies directed at wood technology.

\section{ACKNOWLEDGEMENTS}

We would like to thank the Post-Graduate Program in Ecology and Conservation - PPEC -, and the Federal University of Sergipe - UFS - for providing the laboratory and academic training conditions necessary to conduct this study, as well as the State Secretariat for Environment and Water Resources - SEMARH/SE - and Mr. Paulo Chaves (in memoriam) for logistics and assistance in field campaigns.

\section{SUBMISSION STATUS}

Received: 4 oct., 2017

Accepted: 24 jan., 2018

\section{CORRESPONDENCE TO}

\section{José Roberto Vieira Aragão}

Universidade Federal de Sergipe - UFS, Av. Marechal Rondon, s/n, CEP 49100-000, São Cristovão, SE, Brasil e-mail: craniusru@gmail.com

\section{FINANCIAL SUPPORT}

Scholarship CAPES - Coordenação de Aperfeiçoamento de Pessoal de Nível Superior, Grant/Award Number: 1475259.

\section{REFERENCES}

Albuquerque UP, Araújo EL, El-Deir ACA, Lima ALA, Souto A, Bezerra BM et al. Caatinga revisited: ecology and conservation of an important seasonal dry forest. The Scientific World Journal 2012; 2012: 1-18. http://dx.doi. org/10.1100/2012/205182. PMid:22919296.

Anderegg WRL, Meinzer FC. Wood anatomy and plant hydraulics in a changing climate. In: Hacke U, editor. Functional and ecological xylem anatomy. Cham: Springer International Publishing; 2015. p. 235-53. http://dx.doi. org/10.1007/978-3-319-15783-2_9.

Andrade LA, Pereira IM, Leite UT, Barbosa MRV. Analyses of the stract of two Caatinga physionomy in São João do Dariri, Paraiba state. Cerne 2015; 11: 253-262.

Apgaua DMG, Tng DYP, Cernusak LA, Cheesman AW, Santos RM, Edwards WJ et al. Plant functional groups within a tropical forest exhibit different wood functional anatomy. Functional Ecology 2017; 31(3): 582-591. http:// dx.doi.org/10.1111/1365-2435.12787. 
Araújo EL, Castro CC, Albuquerque UP. Dynamics of Brazilian Caatinga-a review concerning the plants, environment and people. Funct Ecosyst Communities 2007; 1: 15-28.

Araujo KD, Dantas RT, Andrade AP, Parente HN, Alencar MLS. Caracterização do sistema de exploração da Caatinga em São João do Cariri-PB. Geogr Londrina 2010; 19: 175-189.

Araújo SMS. A região semiárida do Nordeste do Brasil: questões ambientais e possibilidades de uso sustentável dos recursos. FASETE 2011; 5: 10.

Baas P, Wheeler EA. Wood anatomy and climate change. In: Hodkinson T, Jones M, Waldren S, Parnell J, editors. Climate change, ecology and systematics. Cambridge: Cambridge University Press; 2011. p. 141-55. http:// dx.doi.org/10.1017/CBO9780511974540.007.

Benites PKRM, Gouvêa AFG, Carvalho AMML, Silva FC. Caracterização anatômica das fibras de oito espécies florestais do Cerrado de Mato Grosso do Sul para a Produção de Papel. Revista Ciência da Madeira 2015;6:88-93. http:// dx.doi.org/10.12953/2177-6830/rcm.v6n2p88-93.

Bomfim LFC, Costa IVG, Benveniti SMP. Diagnóstico do município de Porto da Folha. Aracaju: SEMARH; 2002.

Bonan GB. Forests and climate change: forcings, feedbacks, and the climate benefits of forests. Science 2008; 320(5882): 1444-1449. http://dx.doi.org/10.1126/science.1155121. PMid:18556546.

Brand MA, Lacerda SR, Oliveira J, Lopes GPRD, Casagrande NB. Storage of caatinga forest biomass to improve the quality of wood for energy. Ciência Rural 2016; 46(7): 1178-1184. http://dx.doi.org/10.1590/0103-8478cr20130959.

Brown FBH. The preparation and treatment of woods for microscopic study. Bulletin of the Torrey Botanical Club 1919; 46(4): 1-127. http://dx.doi.org/10.2307/2479494.

Brunner I, Herzog C, Dawes MA, Arend M, Sperisen C. How tree roots respond to drought. Frontiers in Plant Science 2015; 6: 1-16. http://dx.doi.org/10.3389/fpls.2015.00547. PMid:26284083.

Carlquist S. Ecological factors in wood evolution: a floristic approach. American Journal of Botany 1977; 64(7): 886-96. http://dx.doi.org/10.2307/2442382.

Carlquist S. Comparative wood anatomy: systematic, ecological, and evolutionary aspects of dicotyledon wood. 2nd ed. Berlin: Springer Berlin; 2010. Softcover version of original hardcover edition 2001.

Carvalho ECD, Souza BC, Trovão DM BM. Ecological succession in two remnants of the Caatinga in the semiarid tropics of Brazil. Revista Brasileira de Biociências 2012; 10: 13-19.

Costa GM, Cardoso D, de Queiroz LP, Conceição AA. Variações locais na riqueza florística em duas ecorregiões de caatinga. Rodriguésia 2015; 66(3): 685-709. http:// dx.doi.org/10.1590/2175-7860201566303.
Ferraz RC, Mello AA, Ferreira RA, Prata APN. Levantamento fitossociológico em área de Caatinga no monumento natural Grota do Angico, Sergipe, Brasil. Revista Caatinga 2013; 26: 89-98.

Figueirôa JM, Pareyn FGC, Araújo EL, Silva CE, Santos VF, Cutler DF et al. Effects of cutting regimes in the dry and wet season on survival and sprouting of woody species from the semi-arid caatinga of northeast Brazil. Forest Ecology and Management 2006; 229(1-3): 294-303. http://dx.doi.org/10.1016/j.foreco.2006.04.008.

Foelkel CEB, Barrichelo LEG. Relações entre características da madeira e propriedades da celulose e papel. O Pap 1975; 36: 49-53.

Gandolfi S, Leitão-Filho HF, Bezerra CLF. Floristic survey and succession of shrub and tree species of one mesophytic semideciduous forest in the Guarulhos Municipality, SP. Revista Brasileira de Biologia 1995; 55: 1-18. PMid:8729269.

Gleason SM, Westoby M, Jansen S, Choat B, Hacke UG, Pratt RB et al. Weak tradeoff between xylem safety and xylem-specific hydraulic efficiency across the world's woody plant species. The New Phytologist 2016; 209(1): 123-136. http://dx.doi.org/10.1111/nph.13646. PMid:26378984.

Johansen DA. Plant microtechnique. USA: McGraw-Hill Book Co. Inc; 1940.

Jungles AE, Schadeck R, Krüger JEB. Atlas brasileiro de desastres naturais 1991 a 2010: volume Sergipe. Florianópolis: CEPED UFSC; 2011.

Köppen W. Climatologia. México: Fondo de Cultura Econômica; 1948.

Longui EL, Lima IL, Florsheim SMB, Bufalo A. Variação anatômica radial do lenho de açoita-cavalo (Luehea divaricata) e sua influência na densidade aparente. Rev Inst Florest 2009; 21: 181-190.

Oliveira DG, Prata APN, Souto LS, Ferreira RA. Does the edge effect influence plant community structure in a tropical dry forest? Revista Árvore 2013; 37(2): 311-320. http://dx.doi.org/10.1590/S0100-67622013000200012.

Pan Y, Birdsey RA, Fang J, Houghton R, Kauppi PE, Kurz WA et al. A large and persistent carbon sink in the World's Forests. Science 2011; 333(6045): 988-993. http://dx.doi. org/10.1126/science.1201609. PMid:21764754.

Pineda-García F, Paz H, Meinzer FC, Angeles G. Exploiting water versus tolerating drought: water-use strategies of trees in a secondary successional tropical dry forest. Tree Physiology 2015; 36(2): 208-217. PMid:26687176.

Reich PB. The world-wide 'fast-slow' plant economics spectrum: a traits manifesto. Journal of Ecology 2014; 102(2): 275-301. http://dx.doi.org/10.1111/1365-2745.12211.

Roque RM, Tomazello M Fo, Dias CTS. Variações na estrutura da anatomia do lenho de árvores de Gmelina arborea Roxb.(Verbenaceae) de clima tropical seco e úmido na Costa Rica Wood anatomical variation of Gmelina arborea Roxb.(Verbenaceae) trees from dry 
and wet tropical climatic in Costa Rica. Scientia Forestalis 2007; 75: 65-75.

Runkel ROH. Pulp from tropical wood. Vol. 35. HamburgReinbek: TAAP; 1952.

Santos MG, Oliveira MT, Figueiredo KV, Falcão HM, Arruda ECP, Almeida-Cortez J et al. Caatinga, the Brazilian dry tropical forest: can it tolerate climate changes? Theoretical and Experimental Plant Physiology 2014; 26(1): 83-99. http://dx.doi.org/10.1007/s40626-014-0008-0.

Schmidt IB, Ticktin T. When lessons from population models and local ecological knowledge coincide - effects of flower stalk harvesting in the Brazilian savanna. Biological Conservation 2012; 152: 187-195. http://dx.doi. org/10.1016/j.biocon.2012.03.018.

Secretaria do Estado Meio Ambiente e Recursos Hídricos - SEMARH. Plano de Manejo do Monumento Natural Grota do Angico. Sergipe: Secretaria do Estado Meio Ambiente e Recursos Hídricos; 2016.

Silva ACC, Prata APN, Souto LS, Mello AA. Aspectos de ecologia de paisagem e ameaças à biodiversidade em uma unidade de conservação na Caatinga, em Sergipe. Revista Árvore 2013; 37(3): 479-90.

Silva N, Lucena RFP, Lima JRF, Lima GDS, Carvalho TKN, Sousa SP Jr et al. Conhecimento e uso da vegetação nativa da caatinga em uma comunidade Rural da Paraíba, Nordeste do Brasil. Boletim do Museu de Biologia Mello Leitão 2014; 34: 5-37.

Wheeler EA, Baas P, Gasson PE. IAWA list of microscopic features for hardwood identification. IAWA Bulletin 1989; 10: 221-332.

WorldClim [online]. 2017 [cited 2017 Oct 4]. Available from: http://www.worldclim.org

Wright SJ. The future of tropical forests: future tropical forests. Annals of the New York Academy of Sciences 2010; 1195(1): 1-27. http://dx.doi.org/10.1111/j.17496632.2010.05455.x. PMid:20536814.

Zanne AE, Westoby M, Falster DS, Ackerly DD, Loarie SR, Arnold SEJ et al. Angiosperm wood structure: global patterns in vessel anatomy and their relation to wood density and potential conductivity. American Journal of Botany 2010; 97(2): 207-215. http://dx.doi.org/10.3732/ ajb.0900178. PMid:21622380.

Zuidema PA, Baker PJ, Groenendijk P, Schippers P, van der Sleen P, Vlam M et al. Tropical forests and global change: filling knowledge gaps. Trends in Plant Science 2013; 18(8): 413-419. http://dx.doi.org/10.1016/j.tplants.2013.05.006. PMid:23809291. 